Journal of Nonformal Education and Community Empowerment

Volume 1 (2): 137-145, Desember 2017

Available at http://journal.unnes.ac.id/sju/index.php/jnfc

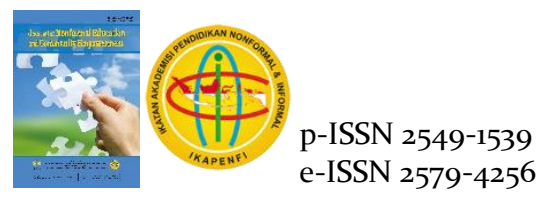

\title{
Peranan Kader Bina Keluarga Balita dalam Optimalisasi Tumbuh Kembang Fisik Motorik Anak Usia Dini
}

\author{
Siska Setianingrum ${ }^{凶}$, Liliek Desmawati, Amin Yusuf \\ Pendidikan Luar Sekolah, Fakultas Ilmu Pendidikan, Universitas Negeri Semarang
}

DOI: 10.15294/pls.v1i2.13891

\section{Info Artikel}

Sejarah Artikel:

Diterima April 2017

Disetujui September 2017

Dipublikasikan Desember 2017

\section{Keywords:}

role of cadres; early childhood development; physical, motoric; family toddler

\begin{abstract}
Abstrak
Penelitian ini bertujuan mendeskripsikan pelaksanaan kegiatan, peran kader, serta faktor pendukung dan penghambat optimalisasi tumbuh kembang fisik motorik anak usia dini di Bina Keluarga Balita dengan menggunakan pendekatan penelitian kualitatif. Subjek penelitian adalah empat orang kader, sepuluh keluarga balita, dan satu PLKB. Metode pengumpulan data menggunakan observasi, wawancara, dan dokumentasi. Keabsahan data dibuktikan dengan triangulasi sumber dan metode. Hasil yang diperoleh bahwa pelaksanaan kegiatan terdiri dari kegiatan pembukaan, inti, dan penutup. Optimalisasi tumbuh kembang fisik motorik anak usia dini yaitu dengan mengetahui tahap perkembangan anak, memberikan kebutuhan anak, menimbang tiap bulan, menjaga kebersihan anak dan lingkungan. Peran kader mencakup peran sebagai pelaksana kegiatan, penyuluh, dan motivator. Faktor pendukung antara lain partisipasi peserta, dan dukungan pemerintah setempat. Faktor penghambat kurangnya pemahaman kader dengan materi, jumlah kader, dan kesibukan peserta.
\end{abstract}

\begin{abstract}
This study aims to describe the implementation of activities, the role of cadres, the optimization of physical and motor development of early childhood, as well as supporting and inhibiting factors in Bina Keluarga Balita using a qualitative research approach. Research subjects were four cadres, ten toddlers, and one PLKB. Methods of data collection using observation, interviews, and documentation. The validity of the data is evidenced by triangulation of sources and methods. The results obtained that the implementation of activities consists of opening, core, and closing activities. Optimalization of physical and motor development of early childhood is to know the stage of child development, provide the needs of children, weigh each month, keep the child and the environment clean. The role of the cadre includes the role of implementing activities, extensionists, and motivators. Supporting factors include participant participation, and local government support. Factors inhibiting the lack of understanding of cadres with the material, the number of cadres, and the busyness of the participants.
\end{abstract}




\section{PENDAHULUAN}

Tumbuh kembang merupakan dua peristiwa yang sifatnya berbeda, tetapi saling berkaitan dan sulit dipisahkan, yaitu pertumbuhan dan perkembangan. Kebutuhan dasar anak untuk tumbuh kembang, secara umum di golongkan menjadi tiga kebutuhan dasar yaitu kebutuhan asuh, asih, dan asah. Para ahli mengatakan bahwa masa balita tersebut sebagai masa emas "golden age period" khususnya pada usia 0-2 tahun perkembangan otak mencapai $80 \%$. Apabila pada masa tersebut anak balita tidak dibina secara baik, maka anak tersebut akan mengalami gangguan perkembangan baik emosi, sosial, mental, intelektual, dan moral yang akan sangat menentukan sikap serta nilai pola perilaku seseorang dikemudian hari (BKKBN, 2009). Hasil pertumbuhan antara lain berwujud bertambah panjangnya badan anak; tubuh bertambah berat; tulang-tulang jadi lebih besar, panjang, berat, kuat, perubahan dalam sistem persyarafan; dan perubahan-perubahan pada struktur jasmaniah lainnya. Dengan begitu, pertumbuhan dapat disebutkan pula sebagai proses perubahan dan proses pematangan fisik. Seiring dengan proses pertumbuhan anak-anak pun mengalami proses lanjutan yang disebut dengan proses perkembangan.

Sedangkan Perkembangan dalam pengertian sempit dapat disebutkan sebagai proses pematangan fungsi-fungsi yang non fisik. Perkembangan ialah perubahan-perubahan psiko fisik sebagai hasil dari proses pematangan fungsi-fungsi psikis dan fisik pada anak, ditunjang oleh faktor lingkungan dan proses belajar dalam passage waktu tertentu menuju kedewasaan. Perkembangan dapat diartikan pula sebagai proses transmisi dari konstitusi psiko-fisik yang herediter, dirangsang oleh faktor-faktor lingkungan yang menguntungkan, dalam perwujudan proses aktif menjadi secara kontinu (Kartono, 2007). Demikian yang diutarakan Hoerniasih (2017) bahwa layanan pengasuhan anak diberikan secara holistik melayani seluruh kebutuhannya untuk tumbuh dan berkembang baik dari kesehatan, gizi, pendidikan, dan perindungan serta secara integratif melakukan kerjasama dengan pihak lembaga pendidikan.

Setelah lahir seorang bayi, pasangan suami istri otomatis akan bertambah perannya dengan menjadi orangtua baru. Mereka harus mempersiapkan segala sesuatunya sebagai sebuah keluarga. Mereka harus mendominasi pada proses pengembangan pribadi bagi si anak. Salah satunya dengan membuat kondisi keluarga yang menyenangkan dan menimbulkan rasa nyaman bagi seluruh anggota keluarga, terutama anak. Mengingat hebatnya pengaruh perlakuan orangtua pada anak khususnya pada usia balita, maka segala tindakan kita dalam mengasuh dan membimbing anak harus terkontrol.

Data Dinas Kesehatan (2014) di tahun 2011, semua Puskesmas telah melaksanakan program deteksi dini tumbuh kembang anak balita dan pra sekolah (usia 1-5 tahun). Cakupan yang dicapai sebesar $86,93 \%$, sedikit mengalami penurunan dibandingkan cakupan tahun 2010. Bila dibandingkan dengan target Kabupaten Semarang tahun 2011 sebesar 30\%, maka cakupan tahun 2011 telah mencapai target, meskipun cakupannya masih perlu terus ditingkatkan agar tidak mengalami penurunan. Sedangkan untuk Siswa SD keseluruhan sudah dilaksanakan pemeriksaan. Sebagian besar Puskesmas telah dapat memenuhi target pemeriksaan siswa SD di tahun 2010 (100\%).

Tumbuh kembang anak usia dini meliputi beberapa aspek, salah satunya yaitu aspek fisik motorik. Wiyani (2014) menyatakan bahwa fisik secara bahasa diartikan sebagai jasmani, badan, tubuh. Sedangkan motorik diartikan dengan penggerak. Jadi perkembangan fisik-motorik anak usia dini dapat diartikan sebagai perubahan bentuk tubuh pada anak usia dini yang berperngaruh terhadap keterampilan gerak tubuhnya. Terkait dengan perkembangan fisik pada anak usia dini tersebut, Kuhlen \& Thompson dalam (Wiyani, 2014) mengemukakan bahwa perkembangan fisik pada individu meliputi empat aspek, yaitu (1) sistem syaraf yang sangat berpengaruh pada aspek perkembangan kognitif dan emosinya, (2) otototot yang mempengaruhi perkembangan 
kekuatan dan kemampuan motoriknya, (3) kelenjar endogrin yang menyebabkan munculnya pola-pola perilaku baru, dan (4) struktur fisik/tubuh yang meliputi tinggi, berat, dan proporsi. Adapun menurut Manna (2014:48)

"Growth and physical maturation are dynamic processes encompassing a broad spectrum of cellular and somatic changes. The most obvious signs of physical growth are changes in overall body size. Changes in size, proportions, and muscle strength support an explosion of new gross-motor skills".

Dapat diartikan bahwa pertumbuhan dan pematangan fisik adalah proses dinamis meliputi spektrum yang luas dari perubahan seluler dan somatik. Tanda-tanda yang paling jelas dari pertumbuhan fisik adalah perubahan dalam ukuran tubuh secara keseluruhan. Perubahan ukuran, proporsi, dan kekuatan otot mendukung ledakan keterampilan motorik kasar baru. Pertumbuhan fisik anak diharapkan dapat terjadi secara optimal karena secara langsung maupun tidak langsung akan mempengaruhi perilaku anak sehari-harinya. Secara langsung, pertumbuhan fisik anak akan menentukan keterampilannya dalam bergerak. Misalnya, anak usia empat tahun yang bentuk tubuhnya sesuai dengan usianya, akan melakukan hal-hal yang lazim dilakukan seusianya, seperti bermain dan bergaul dengan lingkungan keluarga dan teman-temannya. Apabila ia mengalami hambatan tertentu, seperti tubuhnya terlalu gemuk atau malas dan lemas bergerak, anak akan sulit mengikuti permainan yang dilakukan oleh teman-teman sebayanya.

Setyowati (2005) mengungkapkan bahwa penerapan pola komunikasi sebagai bentuk interaksi antara orangtua dengan anak memiliki pengaruh terhadap perkembangan anak. Anak dapat belajar mengenal dirinya sendiri bahkan perasaan sendiri maupun orang lain. Dari hasil pengamatan peneliti selama melaksanakan Praktik Pengalaman Lapangan (PPL) pada bulan Juli-Oktober 2016 di Badan Keluarga Berencana dan Pemberdayaan Perempuan (BKBPP) Kabupaten Semarang dapat diperoleh informasi bahwa tingkat pertumbuhan dan perkembangan fisik-motorik anak usia dini di lingkungan Ngrawan Lor, Kelurahan Bawen masih kurang maksimal. Hal ini tampak pada kondisi fisik anak seperti kegemukan (obesitas), malnutrisi, tinggi dan berat badan anak yang selalu tetap (stagnasi). Dalam perkembangan motoriknya baik motorik kasar maupun halus anak-anak masih sulit untuk menulis, menggambar, melipat-lipat kertas, melompat, dan berlari serta kegiatan anak dalam menggunakan Alat Permainan Edukatif (APE). Ketidakmampuan mengatur keseimbangan, reaksi kurang cepat dan koordinasi kurang baik pada anak pun perlu diperhatikan dan ditangani oleh orangtua.

Optimalisasi tumbuh kembang fisikmotorik anak usia dini adalah salah satu program dari Badan Kependudukan dan Keluarga Berencana (BKKBN). Dalam program ini difokuskan di progam Bina Keluarga Balita (BKB) yang lahir dari prakarsa Menteri Negara Urusan Peranan Wanita, sedangkan untuk pelaksanaan dan pengembangan di masyarakat adalah menjadi tanggung jawab BKKBN. BKB merupakan kelompok kegiatan masyarakat yang bertujuan untuk meningkatkan pengetahuan, sikap dan perilaku serta keterampilan keluarga/orangtua dalam pengasuhan dan pembinaan tumbuh kembang anak. Peran orangtua dalam pengasuhan dan pembinaan tumbuh kembang anak sejak dini (0-5 tahun) atau periode emas sangat penting dan strategis dalam upaya mempersiapkan kualitas sumber daya manusia di masa yang akan dating (Hastasari \& Perwita, 2014).

Layanan BKB ini diperuntukkan bagi ibu yang memiliki balita. Para ibu yang memiliki balita mendapatkan penyuluhan sehingga pengetahuan dan keterampilan ibu dalam mengasuh anak-anak meningkat. Layanan ini telah telah dikembangkan di beberapa negara, termasuk di Indonesia. Pendekatan Bina Keluarga Balita adalah melalui pendidikan orangtua khususnya ibu dan anggota keluarga lainnya. BKB secara kontinu menanamkan kepada orangtua agar tetap memperhatikan perkembangan anak secara komprehensif. BKB sendiri memiliki banyak kegiatan, diantaranya 
adalah kegiatan pelayanan, mulai dari penyuluhan seputar tumbuh kembang anak dan gizi balita. Setiap BKB memiliki beberapa orang kader yang berperan dalam penyelenggaraan program-program pelayanan BKB. Melalui program-program pelayanan yang ada $\mathrm{BKB}$, para kader akan membimbing ibu-ibu anggota BKB dan memberikan keterampilan tentang pola pengasuhan dan mendidik anak yang baik. Pada intinya setiap program yang diselenggarakan oleh BKB menitik beratkan pada pengoptimalan fungsi-fungsi keluarga. dimana peranan fungsi tersebut bertujuan untuk menciptakan kondisi keluarga yang sejahtera.

Data dari BKKBN (2013) di Indonesia sudah banyak terdapat BKB, di wilayah Jawa Tengah jumlah BKB yang ada adalah 1.3316 BKB dengan jumlah anggota BKB sebanyak 324292 anggota dan jumlah kader sebanyak 67244 orang. Di Kabupaten Semarang memiliki 603 BKB dengan 18858 anggota dan 6242 kader. Sementara di Kecamatan Bawen terdapat 20 BKB dengan anggota 373 dan jumlah kader 313 orang yang tersebar di beberapa kelurahan, salah satunya di Kelurahan Bawen sendiri jumlah BKB sebanyak 3 BKB dengan jumlah anggota 46 dan jumlah kader 14 orang. Dengan mengikuti program ini orangtua dapat menjadi lebih pandai mengurus dan merawat anak, pandai membagi waktu dan mengasuh anak. Bertambah wawasan dan pengetahuan tentang pola asuh anak, serta meningkatkan keterampilan dalam mengasuh dan mendidik anak balita.

Berdasarkan uraian yang telah ada, menjadi penting untuk dilakukan adanya penelitian mengenai tumbuh kembang secara fisik motorik pada anak usia dini. Penelitian dilakukan di BKB Siwi Raharjo 4 Rw 05 Kelurahan Bawen Kecamatan Bawen Kabupaten Semarang. BKB ini mempunyai kegiatan penyuluhan diantaranya Kesehatan Keluarga, Sanitasi Gizi, Air Susu Ibu (ASI), Imunisasi, $\mathrm{KB}$, motivasi dan memberkan solusi tentang tumbuh kembang yang dilakukan oleh kader. Pada BKB Siwi Raharjo 4 Kelurahan Bawen memiliki 10 (sepuluh) kader yang terdiri dari 4 kader inti, 3 kader piket, dan 3 kader bantu. Anggota yang mengikuti BKB berjumlah meliputi semua warga Ngrawan Lor RW 5 yang memiliki balita dan seluruh wali murid POS PAUD Siwi Raharjo 4. "Program Bina Keluarga Balita merupakan program yang diperuntukan bagi keluarga yang memiliki balita" (Ariesta, 2011:6). Program Bina Keluarga Balita bertujuan untuk meningkatkan pengelolaan dan keterampilan orangtua dan anggota keluarga lainnya dalam membina tumbuh kembang balita melalui rangsangan fisik, motorik, kecerdasan emosional, dan perilaku sosial, juga merupakan salah satu upaya untuk dapat mengembangkan fungsi pendidikan, sosialisasi, dan kasih sayang dalam keluarga.

\section{METODE}

Berdasarkan pada pokok permasalahan penelitian yang dikaji, yaitu mengenai Peranan Kader Bina Keluarga Balita (BKB) dalam Upaya Optimalisasi Tumbuh Kembang Fisik Motorik Anak Usia Dini maka penelitian ini menggunakan pendekatan deskriptif kualitatif. Penelitian dilaksanakan di BKB Siwi Raharjo 4 Kelurahan Bawen Kecamatan Bawen Kabupaten Semarang. Subjek penelitian merupakan keseluruhan badan atau elemen yang akan diteliti. Adapun yang menjadi subjek penelitian ini adalah Kader Bina Keluarga Balita dan keluarga balita. Jumlah subjek dalam penelitian ini ada 15 orang, yaitu 4 Kader BKB, 10 keluarga balita, 1 PLKB. Subjek penelitian adalah kader BKB Siwi Raharjo 4, sedangkan informan yaitu PLKB Bawen dan orangtua (peserta BKB). Kader BKB di sini merupakan informan utama, sedangkan keluarga balita merupakan informan pendukung.

Fokus penelitian meliputi pelaksanaan kegiatan $\mathrm{BKB}$, peranan kader $\mathrm{BKB}$, faktor pendukung dan penghambat dalam upaya optimalisasi tumbuh kembang fisik motorik anak usia dini. Pengumpulan data dilakukan dengan teknik observasi, wawancara, dan dokumentasi. Keabsahan data dibuktikan dengan triangulasi sumber dan metode. Teknik 
analisis data yang digunakan dimulai dari pengumpulan data, reduksi data, penyajian data dan penarikan kesimpulan/verifikasi.

\section{HASIL DAN PEMBAHASAN}

\section{Pelaksanaan Kegiatan}

Proses pelaksanaan BKB Siwi Raharjo 4 meliputi persiapan, inti, dan penutup. Persiapan yang dilaksanakan di BKB Siwi Raharjo 4 sebelum pelaksanaan kegiatan adalah persiapan Alat Peraga Edukatif (APE) dan tempat. Penyusunan rencana pertemuan yang akan dilaksanakan diatur di awal tahun pertemuan. Penyiapan materi penyuluhan yaitu disesuaikan dengan modul BKB dan kantong wasiat BKKBN. Secara teknis kegiatan BKB Siwi Raharjo 4 telah sesuai dengan petunjuk teknis pelaksanaan BKB.

Pelaksanaan kegiatan pembukaan di BKB Siwi Raharjo 4 antara lain salam, menanyakan kabar, dan pembahasan tugas. Lama kegiatan pembukaan dilaksanakan sekitar 10-15 menit. kegiatan pembukaan dimulai dengan kegiatan pemanasan sebagai pengisi waktu sambil menunggu peserta datang. Penyampaian materi pemanasan dilakukan sebelum pertemuan dimulai oleh kader maupun salah satu seorang peserta. Setelah peserta berkumpul, kader membuka pertemuan dengan kata selamat dating dan berdoa bersama kemudian mengajak orangtua peserta agar peka terhadap peristiwa yang berkaitan dengan pengasuhan dan pengembangan anak usia dini. Kemudian kader mengingatkan kembali hal-hal penting yang telah disampaikan pada pertemuan sebelumnya.

Pelaksanaan dalam kegiatan inti di BKB Siwi Raharjo 4 yaitu penyuluhan pada orangtua balita, balita diajak bermain APE, dan pencatatan Kartu Kembang Anak (KKA). Kegiatan inti dilaksanakan selama kurang lebih 30 menit. Penyampaian materi penyuluhan dilaksanakan oleh kader secara bergantian. Pemanfaatan APE dalam kegiatan BKB Siwi Raharjo 4 sudah baik. Jenis APE cukup beragam dan jumlahnya cukup memenuhi. Sedangkan pada kegiatan KKA, pemanfaatannya sudah sangat baik karena terpadu dengan kegiatan Posyandu. KKA digunakan untuk mengetahui perkembangan anak setiap bulannya.

Pokok dari kegiatan inti adalah bahan baru dan peragaan serta penentuan PR. Pada bahan baru dan peragaan, secara lisan kader menjelaskan topik/kegiatan yang akan dibahas dalam pertemuan hari itu. Sedangkan pada penentuan $\mathrm{PR}$, kader meminta orangtua untuk melatih balita dengan menggunakan alat bantu sesuai topik hari itu.

Kegiatan penutup di BKB Siwi Raharjo 4 meliputi tanya jawab peserta BKB dengan kader, penarikan kesimpulan, dan berdoa bersama. Pada kegiatan tanya jawab tidak banyak perserta yang bertanya, sehingga terkesan pasif dan kurang interaktif. Kegiatan penutup dilaksanakan selama 10-15 menit. Penentuan waktu kegiatan BKB Siwi Raharjo 4 dengan musyawarah antara peserta dan kader. Kegiatan BKB terpadu dengan kegiatan Posyandu, jika kegiatan posyandu di awal bulan sedangkan BKB di akhir bulan. Oleh Ariesta (2011) mengungkapkan bahwa pada kegiatan penutup diadakan beberapa kegiatan antara lain: (1) Kesimpulan hasil pertemuan yang berisi; penegasan untuk memantapkan pengetahuan yang baru diajarkan, keterampilan perlu dilatih agar kemudian dapat dilaksanakan sehari-hari di rumah, adanya perubahan sikap dan nilai sehingga kebiasaan yang kurang baik dihilangkan, dan diganti dengan yang baru karena lebih bermanfaat. (2) Pembersihan ruangan, meskipun ini merupakan tugas para kader, namun ada baiknya peserta diajak membantu, juga pada waktu menyiapkan tempat pertemuan. (3) Peserta pulang, hendaknya dibiasakan untuk meninggalkan tempat pertemuan dengan baik dan saling berpamitan dengan sopan dan ramah. (4) Pertemuan khusus, kegiatan ini dimaksudkan untuk memberikan kesempatan secara pribadi kepada peserta yang memerlukan nasihat khusus dari kader. (5) Pengisian dan pencatatan pelaporan, kegiatan ini tidak perlu dikerjakan di rumah karena bisa mengganggu pekerjaan rutin rumahtangga kader. Untuk memelihara ketertiban/disiplin pertemuan ada baiknya kader lain ikut menemui/membantu, sehingga 
kelalaian/kelemahan kader sebagai tenaga sukarela bisa dikurangi/dicegah.

Kegiatan BKB dilakukan satu kali dalam sebulan. Penanggung jawab umum gerakan BKB adalah Lurah atau Kepala Desa. BKB direncanakan dan dikembangkan oleh kader, LKMD dan PKK serta Tim Pembina LKMD tingkat kecamatan. Dari wawancara pengurus BKB Siwi Raharjo 4 diperoleh data anak usia dini yang mengikuti kegiatan BKB kurang lebih 40 anak yang terbagi menjadi beberapa golongan usia anak. Adapun golongan usia anak terbagi menjadi golongan usia 0-2 tahun, 2-3 tahun, 3-4 tahun dan 4-5 tahun. Pembinaan BKB ditujukan langsung kepada orangtua anak usia dini tersebut yang dilakukan sebanyak 9 kali pertemuan dalam satu tahun dengan topik pembahasan yang berbeda di setiap pertemuaanya.

Secara teknis program BKB ini ditangani oleh kader atau pelatih yang berasal dari daerah masing-masing. Menurut Hibana dalam (Ariesta, 2011:6), "kader dipilih berdasarkan penilaian masyarakat setempat". Tugas kader BKB yaitu memberikan penyuluhan, pengamatan perkembangan, pelayanan, serta memotivasi orangtua untuk merujuk anak yang mengalami masalah tumbuh kembang anak. Oleh karena itu, kader merupakan kunci utama yang menjadi penggerak pelaksanaan kegiatan di daerah tersebut. Di lingkungan masyarakat telah ada berbagai kegiatan yang memberikan layanan kebutuhan dasar anak (yang meliputi pendidikan, pelayanan kesehatan dasar, imunisasi, makanan tambahan dll) seperti Pos Pelayanan Terpadu (Posyandu), Bina Keluarga Balita (BKB), Tempat Penitipan Anak (TPA), Pendidikan Anak Usia Dini (PAUD), kelompok bermain, dan lainnya. Namun penyelenggaraan pelayanan bagi anak usia dini tersebut masih bersifat sektoral, parsial dan belum terintegrasi dengan baik. Seyogyanya pelayanan yang diberikan harus saling bersinergi dan mampu memenuhi kebutuhan dasar anak secara utuh baik dari segi perawatan, pendidikan, dan pengasuhan agar anak tumbuh kembang secara optimal.
Program Bina Keluarga Balita (BKB) sebagai salah satu bentuk pelayanan anak usia dini yang bertujuan meningkatkan pengetahuan dan keterampilan orangtua dalam pengasuhan dan pembinaan tumbuh kembang anak, harus diintegrasikan dengan Program Layanan Anak Usia Dini yang lain, agar anak mendapatkan pelayanan secara utuh. Menurut (BKKBN, 2013) kegiatan kelompok BKB pada dasarnya dilakukan melalui kegiatan penyuluhan dan diskusi atau kegiatan lain yang dianggap perlu. Adapun yang dilakukan pada persiapan kegiatan adalah (a) penyusunan rencana pertemuan, (b) menyiapkan materi penyuluhan, dan (c) merencanakan mekanisme pertemuan yang berupa sarasehan, ceramah, atau dialog interaktif.

Melalui Gerakan BKB diharapkan setiap keluarga akan mampu meningkatkan kemampuannya terutuma dalam membina anakanak balitanya dan anak usia pra sekolah sehingga anak tumbuh dan berkembang secara optimal berkepribadian yang luhur, cerdas serta taqwa kepada Tuhan Yang Maha Esa Materi BKB dirasakan sangat penting diketahui orangtua atau anggota keluarga lainnya agar dapat melaksanakan fungsinya sebagai pendidik pertama dan utama bagi anak balitanya. Dengan mengikuti kegiatan $\mathrm{BKB}$ ini orangtua balita akan lebih memahami perkembangan dan ciriciri khas pada usia tertentu dan mengetahui cara pembinaan yang harus dilakukan agar tumbuh dan berkembang dengan optimal (Farihah \& Masitowarni, 2013). Demikian BKKBN (2013) menyampaikan mengenai tatalaksana kegiatan inti dalam pelaksanaan BKB. Pada kegiatan inti dilakukan selama 30 menit, disini diuraikan mengenai penjelasan bahan baru dan demonstrasi/peragaan cara pengasuhan dan pengembangan anak usia dini. Pada bagian ini, kader memberi penjelasan mengenai materi pertemuan yang akan dibahas pada saat itu, misalnya: materi yang akan disampaikan adalah perkembangan kecerdasan maka langkahlangkah yang harus dilakukan adalah: (1) memberikan penjelasan apa yang dimaksud dengan kecerdasan dan memberikan contoh sesuai dengan kelompok umur yang diasuhnya, 
(2) kemampuan kecerdasan apa saja yang dimiliki anak pada kelompok umur tertentu dan bagaimana cara melatihnya, dan (3) keterkaitan kemampuan tersebut dengan kemampuan lainnya.

\section{Peran Kader}

Kader BKB adalah anggota masyarakat yang bekerja secara sukarela dalam membina dan menyuluh orangtua balita tentang bagaimana mengasuh anak secara baik dan benar (BKKBN, 2008). Dalam hal ini kader BKB Siwi Raharjo 4 masih kurang mendapatkan pendidikan dan pelatihan dari instansi terkait, sehingga pengetahuan dan pemahanan tentang materi-materi BKB masih rendah. Sebelum penyuluhan kader mengidentifikasi apa yang menjadi permasalahan dan kebutuhan dari peserta BKB. Identifikasi tersebut dilakukan dengan tujuan agar materi yang disampaikan dapat tepat sasaran. Rekrutmen kader dilihat dari pengetahuan dan kemampuan kader serta kesenggangan kader. Kader BKB menjalin hubungan mitra dengan PLKB Bawen dan BKKBN Kabupaten Semarang serta kader-kader Posyandu. Sebagai motivator kader memberikan pemahaman tentang pentingnya kesehatan fisik yang menunjang kegiatan anak. Fisik anak yang kuat dan baik akan menimbulkan gerakan dalam kegiatan anak yang optimal. Kader mengarahkan orangtua untuk melakukan tindakan optimalisasi tumbuh kembang fisikmotorik anak, misalnya orangtua diarahkan agar tidak melarang anaknya untuk bermain, karena dengan bermain anak dapat terlatih gerakan tubuhnya. Selain itu, orangtua digerakkan untuk membuat APE sendiri di rumah dan dibawa ketika pertemuan BKB.

Tumbuh kembang anak memiliki dua fase yang berbeda, yaitu pertumbuhan merupakan suatu proses perubahan fisik yang ditandai dengan bertambahnya berbagai ukuran berbagai organ tubuh, dan perkembangan merupakan suatu proses bertambahnya kemampuan dan struktur serta fungsi tubuh yang lebih kompleks sebagai hasil dan pematangan sel-sel. Menurut Dinas Kesehatan (2014) bahwa 16\% balita Indonesia mengalami gangguan perkembangan, baik perkembangan motorik halus dan kasar, gangguan pendengaran, kecerdasan kurang dan keterlambatan bicara. Puskesmas merupakan pelayanan kesehatan masyarakat, akan tetapi tidak dimanfaatkan secara maksimal. Saat ini keaktifan ibu dalam memonitoring tumbuh kembang anaknya mengalami penurunan, dikarenakan kesibukan maupun malas.

Menurut Ismiati (2009) bahwa usia 5 tahun pertama sorang anak adalah usia sangat menentukan. Usia tersebut dikenal dengan istilah golden age atau usia keemasan. Istilah itu muncul karena pada usia tersebut aspek kognitif, fisik, motorik, dan psikososial seorang anak berkembang secara pesat. Salah satu cara untuk mengoptimalkan kemampuan-kemampuan tersebut adalah dengan menstimulasinya (merangsangnya) dengan menggunakan mainan. Memilih mainan harus disesuaikan dengan usia dan tingkat perkembangan anak. Perkembangan fisik pada individu terjadi mengikuti prinsip cephalocaudal, yaitu bahwa kepala dan bagian atas tubuh berkembang lebih dahulu sehingga bagian atas tampak lebih besar daripada bagian bawah. Hal itu dapat terlihat pada bayi dan anak-anak yang memiliki bentuk tubuh berbeda dengan orang dewasa yang mana kepala mereka tampak lebih besar jika dibandingkan dengan bagian tubuh lainnya.

Seorang kader dalam peranannya sebagai pelaksana kegiatan, berperan mempersiapkan semua yang dibutuhkan dalam proses kegiatan. Persiapan ini meliputi persiapan tempat, media penyuluhan dan alat permainan edukatif (APE). Sebelum kegiatan dimulai, kader melakukan koordinasi terlebih dahulu dengan petugas lapangan dan kader lainnya untuk membahas materi yang akan disampaikan saat pertemuan. Sebagai pelaksana kegiatan, kader melakukan perannya dari kegiatan pembuka, kegiatan inti, dan kegiatan penutup. Dalam pelaksanaan kegiataan BKB, kader merupakan salah satu kunci penggerak terlaksananya kegiatan. Kegiatan BKB, kader juga berperan sebagai penyuluh yang bertugas memberikan penyuluhan kepada orangtua balita terkait dengan tumbuh kembang anaknya. Penyuluhan dalam arti umum berarti ilmu sosial yang 
mempelajari sistem dan perubahan pada individu serta masyarakat agar dapat terwujud perubahan yang lebih sesuai dengan apa yang diharapkan. Penyuluhan adalah proses perubahan sosial, ekonomi dan politik untuk memberdayakan dan memperkuat kemampuan semua "stakeholders", melalui proses belajar bersama yang partisipatif, agar terjadi perubahan perilaku pada diri setiap individu dan masyarakatnya untuk mengelola kegiatan yang semakin produktif dan efisien, demi terwujudnya kehidupan yang baik, dan semakin sejahtera secara berkelanjutan.

Dalam pembinaan dan penyuluhan BKB tidak lepas dari peran kader yang aktif dan kreatif agar program BKB dapat terealisasi secara maksimal. Menurut Ahmadi (2007) bahwasannya peran adalah suatu kompleks pengharapan manusia terhadap caranya inividu harus bersikap dan berbuat dalam situasi tertentu yang berdasarkan status dan fungsi sosialnya. Pengertian peran menurut Soekanto (2002) bahwa peran merupakan aspek dinamis kedudukan (status), apabila sesorang melaksanakan hak dan kewajibannya sesuai dengan kedudukannya, maka ia menjalankan suatu peranan. Kader menurut BKKBN (1997) adalah anggota masyarakat yang telah mendapatkan pendidikan serta menjalankan tugasnya dengan sukarela. Kemudian kader tersebut adalah seorang atau sejumlah orang yang memiliki pengetahuan dan keterampilan khusus di bidang tertentu, serta mampu dan mau menyebarluaskan pengetahuan serta keterampilan pada sasarannya secara teratur dan terencana. Dalam setiap kegiatan yang dilakukan sudah terjadwal. Hal ini dapat memfokuskan kepada setiap kader-kader agar lebih maksimal dalam setiap kegiatan yang dilaksanakan.

\section{Faktor Pendukung dan Penghambat}

Berdasarkan hasil penelitian diperoleh faktor-faktor yang mendukung pelaksanaan kegiatan di BKB Siwi Raharjo 4 terdiri dari dua factor, internal dan eksternal. Faktor internal meliputi sarana dan prasarana yang sudah cukup memadai, pembagian tugas kader per kelompok sudah cukup baik, alat permainan edukatif (APE) yang cukup memenuhi kebutuhan anak. Faktor-faktor yang mendukung pelaksanaan kegiatan di BKB Siwi Raharjo secara eksternal mencakup peserta yang antusias saat mengikuti kegiatan, partisipasi dari masyarakat yang sangat baik serta dari pemerintah, pemerintah setempat yang sangat mendukung kegiatan BKB.

Faktor-faktor penghambat dalam kegiatan BKB Siwi Raharjo 4 terbagi menjadi faktor internal dan eksternal. Faktor penghambat secara internal yaitu pembekalan terhadap kader $\mathrm{BKB}$ secara khusus tentang materi $\mathrm{BKB}$ masih kurang, belum tersediannya dukungan dana operasional baik untuk pertemuan/kegiatan $\mathrm{BKB}$ maupun kader $\mathrm{BKB}$, maka penyuluhan kepada orangtua balita sasaran belum dapat terlaksana maksimal secara rutin sesuai pedoman. Oleh karena itu, transfer ilmu tentang tumbuh kembang kepada sasaran BKB belum tercapai secara maksimal. Sedangkan faktor penghambat secara eksternal adalah semua anggota $\mathrm{BKB}$ kadang tidak aktif ikut kegiatan BKB (tidak hadir dalam setiap kegiatan), koordinasi dengan pihak lain belum baik misalnya dengan PLKB dan petugas dari BKKBN, PLKB tidak membina secara optimal karena kurangnya dukungan operasional, tugas serta fungsi PLKB bertambah dengan kelembagaan, antusiasme peserta BKB dalam mengikuti kegiatan BKB masih belum stabil, dan keaktifan dalam menanggapi penyuluhan kurang interaktif.

\section{SIMPULAN}

Proses pelaksanaan BKB Siwi Raharjo 4 meliputi persiapan, inti, dan penutup. Adapun peran kader meliputi peran sebagai pelaksana kegiatan, penyuluh, dan motivator. Dari ketiga peran tersebut, peran sebagai pelaksana kegiatan sudah optimal, namun untuk peran sebagai penyuluh masih kurang optimal. Faktor pendukung kegiatan BKB antara lain dari segi sasaran, partisipasi dan alat permainan tercukupi. Sedangkan faktor penghambatnya antara lain dari segi orangtua, dan keterbatasan kader. 
Sebaiknya kader dalam melakukan penyuluhan diberi pelatihan terlebih dahulu tentang materi yang akan disampaikan sehingga dapat menguasai materi. Kedepannya memberikan kegiatan yang lain seperti berdiskusi dengan memutarkan film agar lebih bervariasi dan lebih menarik minat masyarakat. Kemudian Alat Permainan Edukatif (APE) hendaknya lebih dilengkapi sesuai dengan tahap perkembangan anak. Jumlah kader ditambah untuk memudahkan dalam pemantauan perkembangan anak. Kedepannya lebih digerakkan kembali partisipasi masyarakat dalam mengikuti BKB, agar kegiatan BKB lebih berjalan efektif dan terasa kebermanfaatannya.

\section{DAFTAR PUSTAKA}

Ahmadi, A. (2007). Psikologi sosial. Jakarta: Rineka Cipta.

Ariesta, N. P. (2011). Peran kader bina keluarga balita dalam upaya pembinaan kesejahteraan keluarga melalui layanan bina keluarga balita (studi deskriptif di bkb kasih ibu i kelurahan bulukerto kecamatan bulukerto kabupaten wonogiri). Universitas Negeri Semarang.

BKKBN. (1997). Pedoman bina keluarga balita. Jakarta: BKKBN.

BKKBN. (2008). Pedoman bina keluarga balita. Jakarta: BKKBN.

BKKBN. (2009). Pedoman bina keluarga balita. Jakarta: BKKBN.

BKKBN. (2013). Pedoman bina keluarga balita. Jakarta: BKKBN.

Dinas Kesehatan. (2014). Profil kesehatan kabupaten semarang. Semarang: Dinkes Semarang.

Farihah, F., \& Masitowarni, M. (2013). Pengelolaan kegiatan bina keluarga balita (BKB) secara holistik dan integratif. Jurnal Keluarga Sehat Dan Sejahtera, 11(22), 8-14.

Hastasari, C., \& Perwita, A. H. (2014). Pengembangan model komunikasi pelayanan untuk menghasilkan kader yang kreatif dalam menunjang keberhasilan program bina keluarga balita. Jurnal Komunikator, 6(2).

Hoerniasih, N. (2017). Pengelolaan Program Taman Penitipan Anak Plamboyan 3 di Kabupaten Karawang. Journal of Nonformal Education and Community Empowerment, 1(1), 34-42.

Ismiati, N. S. (2009). 10 program menuju kesejahteraan. Klaten: Cempaka Putih.

Kartono, K. (2007). Psikologi anak (psikologi Perkembangan). Bandung: CV. Mandar Maju.

Manna, I. (2014). Growth development and maturity in children and adolescent: Relation to sport and physical activity. American Journal of Sport Science and Medicine, 2(5A), 48-50.

Setyowati, Y. (2005). Pola komunikasi keluarga dan perkembangan emosi anak (studi kasus penerapan pola komunikasi keluarga dan pengaruhnya terhadap perkembangan emosi anak pada keluarga jawa. Jurnal Ilmu Komunikasi, 2(1), 67-78.

Soekanto, S. (2002). Sosiologi suatu pengantar. Jakarta: Raja Grafindo Persada.

Wiyani, N. A. (2014). Psikologi pengembangan anak usia dini. Yogyakarta: Gava Media. 